\title{
Career Management and Employees' Performance in the Ministry of Education and Vocational Training in Zanzibar
}

\author{
Mina Bacar ${ }^{1}$, Shabaan Mwinchum Suleiman ${ }^{2}$, Nsubuga Haroonah ${ }^{3}$ \\ MPA Student, Zanzibar University, P.O.Box 2440 Zanzibar \\ Staff, Institute of Public Administration, Zanzibar \\ Staff, Zanzibar University
}

\begin{abstract}
This study aimed at examining the relationship between career management and employees' performance in Ministry of Education and Vocational Training (MoEVT) in Zanzibar. Survey research design was employed in this study due to its nature. Data was collected from 95 respondents using questionnaires survey. In order to reach a credible result, an inferential statistical technique was used such as Pearson's Correlation coefficient was used as a data analysis technique to measure the relationship between career management and employee performance in the MoEVT. The findings of the study revealed that, career management correlates moderately with the employee performance by $0.416(42 \%)$. This means that, the increase of career management in the organisation does also lead to increase in employee performance. The study concludes career management can influence the employees' performance by 42 percent only. The study recommends for more improvement in human resources policies in order to achieve better performance as well as higher productivity.
\end{abstract}

Keywords: Career management, employee's performance, Ministry of Education and Vocational Training, Zanzibar

\section{Introduction}

In Tanzania, The Public Service Commission is mandated to ensure that the Public Service is efficient and effective; develop human resources in the Public Service; and review and make recommendations to the National Government in respect of conditions of Service, and qualifications of public officers. This is as provided for under Article 234 (e), (f) and (g) of the Constitution. Further, Section 55 (7) of the Public Service Commission Act, 2017 requires the Commission to establish the necessary structures that will among other purposes provide for career progression and mobility of public officers as part of the career management practice in the Civil Service (PSC, 2018).

Currently, The Civil Service largely uses a number of career management tools to manage employees' careers and policy documents. Some of these include Schemes of Service, staff performance management system, training and development programmes, and the Diversity Policy for the Public Service, among others (PSC, 2018).

In Ministry of Health, the Government tries to implement a lot of policies and practices organization and use career management to prevent valuable employees from leaving their jobs. To counter the significant shortage of qualified professionals, the GoT raised salaries for the health services staffs effective in 2006, $\mathrm{P} 4 \mathrm{P}$ strategies, support payment of salaries to faith based organizations, improved working Environment, promotion of workers and the like (URoT, 2011). 
Despite the efforts done, the ability to retain employees is a challenge due to socioeconomic disparities and other work environment challenges that put off professionals and thereby affecting their retention, particularly in the rural areas. An incentive package and retention strategy need to be developed that will take into account the need to improve performance and management. The use of attractive differential incentive packages including preferential career development should be considered when designing the incentive package (URoT, 2011).

Career management is the process by which individuals collect information about values, interests, skills, strengths and weaknesses, identify a career goal and engage in career strategies that increase the probability for goals to be achieved (Godshalk et.al., 2010). Unlike in the past where organizations focused on employment for work only, today, many organizations have set the mechanisms aiming at implementing career management programs in their work places (Samuel Vivian, 2016). It was however noted by Bemardin (2008) that, the career of the $21^{\text {st }}$ century is measured by continuous learning and identifies changes rather than by chronological age and life changes. Most of organizations call for a number of interventions such as distinguishing organizational broad goals that will intervene their career such as intervention of employees' willingness to be trained, to have skills, to be committed, motivated and satisfied for their development (Samuel, 2016).

When an organization fails to motivate its employees to plan their careers, it can result in a shortage of employees to fill open positions, lower employee commitment and inappropriate use of monies allocated for training and development programs through lower organizational performance (Lyria et.al., 2012).

In Zanzibar, Public Service Commission has a role to ensure of individual career planning and management; however, some departments are not active on this issue. The Ministry of Education is not staying back in planning individual and organizational career management to achieve both individual and organizational goals through providing of training, workshop, promotion, periodic supervision; assessment and rewards are amongst others (Department of Policy and Planning, 2020).

In additional to that, MoEVT promoted 437 employees since 2017, 198 employees were strategically transferred to several departments to develop their career for learning new challenges. 42 employees were trained including 5 females and 2 males in 2017. 4 employees were trained in 2018 including 2 males and 2 females. In 2019, 20 employees were trained including 11 females and 9 males. Lastly 11 employees were trained in 2020 including 4 females and 7 males. All these efforts were taken to develop staff career for the performance of MoEVT (Human Resource Development, 2021).

\section{Literature Review}

\subsection{Career management and Employees' performance.}

There are several studies that have been conducted to establish the link between career management and employee's performance.

According to Patrick \& Kumar (2011) who studied on career management, employee development and performance in India, they are considering the employees at information Technology companies. The study used mixed method through a questionnaire followed by personal interview to collect data from 100 employees of five Indian IT companies to come up with the several findings: One, through career management, employees may grow professional and that leads to establishment of career centres to enhance employees' professional growth as well as employees' performance in organization. Secondly, the paper display that the employee development is sponsored by an effort made by the organization to its workers and focuses on identifying, assuring and evoking new insights through planned learning. Finally, the paper depict that lack of career planning for promotion and individual aspirations with organizational needs and opportunities cause great personal and financial hardship to both the individual and the company.

Marinara (2011) conducted a research on the factors affecting career management among non-academic staff in public Universities in Kenya. This research adopted a descriptive survey design with appropriate methods of data collection. The target population was 1,275 non-academic staff members working for Jomo Kenyata University of Science and Technology (JKUAT). Sample of 130 respondents were selected through 
simple random sampling of non-academic staff members to take part in the study. The study found that, career planning, training and development and institutional framework had a positive effect on career management in JKUAT. This means that career management is affected with the said variables (career planning, training and development and institutional framework) to the performance of non-academic staff. However, the study revealed that work-life balance had a negative effect on career management since employees could not balance their private and work lives effectively. In addition to that, JKUAT did not have a clear career management policy for its non-teaching staff and that, supervisors did not discuss with the non-academic staff ways in which to improve their careers.

Again, Elnaga and Imran (2013) doing a research on the effects of training on employees' performance. A qualitative approach was used as well as reviewing the literature and multiple case studies on the importance of training in enhancing the performance of the workforce. The study has found that career management factors like training found to affect employee's job performance positively. The study concludes along with recommendation to give directions for future research by applying different level of analysis on exploring the impact of training practices on employee performance.

Moreover, Asfaw, Argaw and Bayissa (2015) conducted study on the impact of training and development on employee performance and effectiveness. The study was conducted in Addis Ababa, Ethiopia at District five administration offices. A cross sectional research design was used in this study based on quantitative research method. A systematical random sampling was used in this study to select a sample size of 100 employees as well as questionnaire survey was used for data collection. The study finding shows that training and development had positively correlated and claimed statistically significant relationship with employee performance and effectiveness. The study also concludes and recommended that District Five Administration Office shall maintain providing employee training and development activities and ensure the participation of employees in planning, need or skill deficit identification and evaluation of training and development programs.

Furthermore, a study by Athar and Shah (2015) on the impact of training on employee's performance is conducted in banking sector at Karachi. A quantitative research design was used in this study by adopting a questionnaire survey as a method for data collection techniques. A simple random sampling was also used to select 100 sample sizes to represent all employees of banking sectors at Karachi. Inferential statistical techniques were used such as multiple regressions and correlation, for data analysis in this study. The study found out that, the factors of training have positive impact on employee performance of banks of Karachi. In addition, the feedback and training as motivational factors could enhance the knowledge of employees in a Bank towards job execution by which Banks (employees in Bank) become more proficient at their jobs to and this enables them able to perform better.

Appiah (2010) conducted a study on the impact of training on employee's performance in HFC Bank of Ghana. The study is quantitative in nature and questionnaire survey was used for data collection method. In terms of data analysis, the study used inferential technique (correlation emphasized that, training enabled trainees to cope with the change of technology, innovation or between its training programs and the success of the company). The study found that HFC Bank had a comprehensive (planned and systematic) in house training program that every employee was aware of. The study concludes and recommends that the organizations should ensure that the program is consistently evaluated to ensure its compatibility with global changes and changes within the banking industry

Ans De Vos \& Cambre (2016) carried out a study on Career Management in High Performing Organizations: A set-Theoretic Approach. Surveys were administered to the HR directors of 293 organizations. Fuzzy-set qualitative comparative analysis in complement with more conventional structural equation modelling(SEM).Based on a combined perspective integrating insights from the literature on careers, high performance work systems and idiosyncratic deals (I-deals), four dimensions of OCM were addressed: supportive and developmental practices, development I-deals, individual responsibility and consensus. The findings from SEM analyses suggested that, only supportive and developmental practices are positively associated with high performance. However, based on the fuzzy-set qualitative comparative 
analysis, (fsQCA), three configurations are identified in which organizational career management (OCM) is associated with high performance. The most prevalent configuration combined supportive and developmental practices with I-deals and individual responsibility for career management.

\section{Methodology}

The aim of this study was to examine the relationship between career management and employee's performance at the Ministry of Education and Vocational Training in Zanzibar. Survey research design was employed. Survey design was appropriate for this study because it allowed collection of information for independent and dependent variables by using questionnaires (Orodho, 2003). For the purpose of data, the researchers used scientific method to calculate the Cumulative Volume Index (CVI) by distributing 26 questionnaires (using 5 Likert scale) to some respondents in the Ministry of Education and Vocational Training Zanzibar (MoEVT). The results showed that, out of the 26 questionnaires distributed, 24, were returned and complete were 23, returned but incomplete was 1 and 2 of them were missed due to various reasons. The results of the test scored at 0.923 alphas found to be above a standard of 0.5 in a range of 0 to 1 which is more accepted according Not \& Flinger (2013). Crobachs Alpha test was used to measure the reliability of the instrument and the results showed that, the reliability test of five (5) variables that is training, motivational packages, career feedback and employee performance are $0.537,0.641,0.655$ and 0.685 respectively. These scores are above the acceptable range of 0.5 (Pallant, 2007, Notz \& Flinger, 2013). Therefore; it can be concluded that, the instrument used in collecting data was consistent and reliable.

\subsection{Results and Discussion}

\subsection{Demographic Analysis of the Respondents}

Generally, one may not see the importance of including demographic data in this study since it is not part of the research objective(s). However, for the betterment of this work, the researchers decided to include the basic characteristics of respondents like gender, age, level of education, marital status, working experience, occupation of the respondents as well as a number of dependents managed by employee since they add the value to this study. For example, in observing the objective like income of the respondents towards satisfactory or building of organizational climate, then, to know the number of dependents in advance could assist pretty enough in making comparison or studying a relationship between low income staff with higher number of dependents and level of work satisfaction. By that purpose, the researchers deeply studied characteristics of the respondents. The findings are depicted in Table 1.

Table 1: Profile of the Respondents

\begin{tabular}{|l|l|l|}
\hline Variable & Category & Percentage (\%) \\
\hline Gender & Male & 60 \\
& Female & 40 \\
\hline Age & less than 21 years21-30 years & 3 \\
& $31-40$ years & 36 \\
& $41-50$ years & 31 \\
& $51-60$ years & 28 \\
& Shopkeeper & 2 \\
\hline Occupation & Vendor & 1 \\
& etc & 1 \\
\hline Marital status & single & 98 \\
& married & 16 \\
& divorced & 64 \\
& & 18 \\
\hline Level of education & Form 4 & 3 \\
& Form 6 & 5 \\
& Certificate & 11 \\
& Diplomat & 15 \\
& Bachelor & 51 \\
\hline
\end{tabular}




\begin{tabular}{|l|l|l|}
\hline & Post graduate & 12 \\
\hline Working experience & 1 year & 16 \\
& 1-5 years & 41 \\
& 6-10 years & 7 \\
& $11-15$ years & 13 \\
& $16-20$ years & 8 \\
& 21 and more & 12 \\
\hline Number of dependants & $1-2$ & 21 \\
& $3-4$ & 34 \\
& $5-6$ & 23 \\
& $7-8$ & 14 \\
& $9+$ & 2 \\
& None & 6 \\
\hline
\end{tabular}

Source: Field data, 2020

\section{2: Correlation Analysis}

In order to achieve this objective, the bivariate correlation was conducted using Pearson's correlation coefficient (r). According to Pallant (2016), correlation analysis is basically applied to explain the strength and direction of the linear relationship between two variables (bivariate correlation). In line with this explanation, correlation analysis was specifically carried out in order to see the strength and direction of the independent variable; that is career management and dependent variable that is employee performance.

However, in interpreting the Pearson's Correlation coefficient, the commonly used scholar whom many researchers refer to is Jacob Cohen (1988) (Pallant, 2016). According to Cohen (1988), Pearson's correlation coefficient is classified into three sizes namely small $(r=0.10-0.29)$, medium $(r=0.30-0.49)$ and large $(0.50-1.0)$. The findings are depicted in Table 2.

Table 2: Interpretation of Pearson correlations coefficient(r)

\begin{tabular}{|ll|}
\hline Value of Pearson correlation coefficient & \multicolumn{1}{c|}{ interpretation } \\
\hline $\mathrm{R}=0.10$ to 0.29 & Small correlation \\
$\mathrm{R}=0.30$ to 0.49 & Medium correlation \\
$\mathrm{R}=0.50 \mathrm{TO} 1.0$ & Large correlation \\
\hline
\end{tabular}

Source: Cohen (1988, pg79)

The results of the Pearson's correlation coefficient (r) in Table 2 showed that, the predictor variable namely; Career management correlate positively with the dependent variable; employee performance. Analysis of this correlation is provided in Table 3.

Table 3: Correlation Analysis

\begin{tabular}{|ll|c|c|}
\hline & & $\begin{array}{c}\text { Career } \\
\text { management }\end{array}$ & $\begin{array}{c}\text { Employee } \\
\text { performance }\end{array}$ \\
\hline Career management & $\begin{array}{l}\text { Pearson } \\
\text { Correlation }\end{array}$ & 1 & $.416^{* *}$ \\
& Sig. (2-tailed) & & .000 \\
& $\mathrm{~N}$ & 95 & 95 \\
\hline Employee performance & Pearson & $.416^{* *}$ & 1 \\
& Correlation & .000 & \\
& Sig. (2-tailed) & 95 & 95 \\
& $\mathrm{~N}$ & & \\
\hline
\end{tabular}

Source: Field data, 2020 
Table 3 shows that, career management correlate with the employee performance moderately by 0.416 $(42 \%)$ while two tailed shows that, career management significantly correlates with employee performance for 0.01 level. This means that, career management significantly influences employee performance because it is less than 0.05 values. This means that, when career management in the organization increases, it leads to an increase in employee performance as well.

The findings are in line with the work of Patrick and Kumar (2011) in India who found out that, through career management, employees may grow professional and that influences the establishment of career centres to enhance employees' professional growth and performance.

It was also added by Ans De Vos \& Cambre B. (2016) that, in strong support and developmental practices, development I-deals, individual responsibility and consensus; career management positively is associated with high performance in higher performing organisation in the World. Despite this existing fact, some conditions like career management, supportive environment, could provide an impact on the performance of employees.

\section{Conclusion}

This paper described the relationship between career management and employees' performance in Ministry of Education and Vocational Training (MoEVT) in Zanzibar. Based on the study findings, the concludes that career management correlates with employee performance moderately by $0.416(42 \%)$ while two tailed shows that, career management significantly correlates with employee performance for 0.01 level at the Ministry of Education and Vocational Training in Zanzibar.

\section{Recommendations}

Based on the conclusion above the study is recommending the following aspects that should be taken by the responsible authorities in the study area.

i. With the purpose of encouraging employees to perform, the government or the Ministry of Education and Vocational Training should continue to update human resource policies like career management to meet maximum point of utilizing employees at the Ministry. This is so because these kinds of policies correlated with performance improvement.

ii. Government should continue providing adequate funds to support training programs in the organizations, funds for continuous improvement of the salary and allowance regimes of staff as well as timely provision of information to staff for their rights or benefits.

iii. Government should keep creating an enabling environment for the development of career management policies so as to create and maintain good organizational climate in its Ministries in Zanzibar

\section{References}

1. Ans De Vos \& Cambre B. (2016). Career Management in High Performing Organizations: A setTheoretic Approach. Berlin: Research Gate Publication No. 301304194.

2. Asfaw,A.M., Argaw,M.D. and Bayissa,L. (2015). The Impact of Training and Development on Employee Performance and Effectiveness: A Case Study of District Five Administration Office, Bole Sub-City, Addis Ababa, Ethiopia. Journal of Human Resource and Sustainability Studies, Vol.3 No.4,

3. Athar, R., \& Shah, F. M. (2015), Impact of training on employee performance (banking sector Karachi). IOSR Journal of Business and Management, 17(11), 58-67.

4. Bernadin, H. J. (2008). Human Resource Management: An Experiential Approach. New Delhi: McGraw Hill.

5. Bowditch \& Buono. (2019). Organizational climate: meaning, characteristics and factors.UK: Essays.

6. Cohen, J.W. 1988. Statistical Power Analysis for the Behavioral Sciences (2nd ed.). Hillsdale, New Jersey: Lawrence Erlbaum Associates. 
7. Department of Policy and Planning-(DPP). (2020). Individual survey: Ministry Information. (Unpublished)

8. Elnaga, A., \& Imran, A. (2013). The effect of training on employee performance.European Journal of Business and Management, 5(4), 137-147.

9. Godshalk, V, Greenhaus, J., \& Callanan, A. (2010).Career Management. USA: Sage Publications CA.

10. Kumar A, Patrick R. (2011). Career Management, Employee Development and Performance in India Information Technology Organizations. India: Business Management Dynamics.

11. Lyria R \& Kabare K. (2012). Effect of Career Management to the Organizational Performance in Companies Listed in Nairobi Security Exchange: Kenya. International Journal of Science and Research.

12. Maina A. (2011), factors affecting career management among non-academic staff in public Universities in Kenya: a case study of Jomo Kenyatta University of Agriculture and Technology. Kenya: Master Degree Dissertation of Jomo Kenyatta University.

13. Ministry of Education and Vocational Training (MoEVT). (2021). Physical survey: Department of Human Resource. (Unpublished)

14. Notz, W. I, \& Flinger, M. A. (2013). The basic practice of statistics (6th ed.). New York, NY: W. H. Freeman and Company.

15. Orodho, J.A. (2005). Techniques of writing Research Proposals and Reports in Education and Social Sciences. Nairobi: Kenya HP enterprises.

16. Pallant, J. (2016). SPSS Survival Manual (6th ed.). New York, United States of America:- McGrawHill.

17. Patrick H.A\& Kumar A. (2011).Career management, Employee Development and Performance in India Information Technology Organization. India, Business Management Dynamics.

18. Public Service Commission-(PSC). (2018). Aguide for Career Management in the Civil Service, Tanzania: Public service Report.

19. Samuel V. (2016).Challenges Facing Employees' Career Development: The Case of Medical Stores Department Staff. Tanzania:- Master Degree Dissertation of Open University.

20. United Republic of Tanzania-(URoT). (2011). Guideline for Data utilization of Human Resource for Health Information System (HRHIS) and Training Institution Information System (TIIS)“ For better planning, management, and development of HRH. Tanzania:- health information system Report. Universiti Utara Malaysia. 